\title{
Microbiological Identification of Atmospheric Particles in Hermosillo, Sonora, México
}

\author{
Santos-Romo Alvaro1, Sau-Acosta Nancy Janeth1, Certucha-Barragán María Teresa², \\ Almendáriz-Tapia Francisco Javier², Monge-Amaya Onofre², Hernández-López Jorge¹, \\ Zepeda-Ibarra Joel ${ }^{3}$ \\ ${ }^{1}$ Nortwest Biologicallnvestigation Centre, Hermosillo, Mexico \\ ${ }^{2}$ Department of Chemical Engineering \& Metallurgy within the Engineering Division of the University of Sonora, \\ Hermosillo, Mexico \\ ${ }^{3}$ Urban Development and Ecology, General Coordination of Infrastructure, Municipal Institute of Ecology, \\ Hermosillo, Mexico \\ Email: jhlopez04@cibnor.mx
}

Received 18 February 2014; revised 16 March 2014; accepted 12 April 2014

Copyright (C) 2014 by authors and Scientific Research Publishing Inc.

This work is licensed under the Creative Commons Attribution International License (CC BY). http://creativecommons.org/licenses/by/4.0/

(c) (i) Open Access

\section{Abstract}

The air quality in many cities has been deteriorating and affecting population's health. Airborne particles can block the defense mechanisms of respiratory system and may lead biological elements such as pollen, bacteria, fungi and viruses into the lungs. This paper presents the study of biologically contaminated air in the city of Hermosillo, analyzing filters containing particulate matter with a diameter equal or less than 10 micrometers $\left(\mathrm{PM}_{10}\right)$ and Total Suspended Particles (TSP). Three sampling periods were analyzed during 2011. Samples taken from the filters were placed in tubes containing nutritive broth BHI (Brain Heart Infusion) and incubated at $37^{\circ} \mathrm{C}$ for 24 hours. The identification of the isolated microorganisms was done by a biochemical test recommended in Bergey's Manual. Results showed a high bacteria concentration in the presence of microorganisms such as Klebsiella pneumoniae sub pneumoniae, Citrobacter, Enterococcus faecalis, Proteus penneri, Butiauxellaagrestis, Salmonella paratyphi $A$ and Enterobacter sacazakii. When bacterial concentration was analyzed separately, the lowest number of bacteria was observed during February for the south location and in August for the north location. The highest degree of bacterial air pollution was found in the central area of the city.

\section{Keywords}

Air Pollution, Airborne Particles, Bacteria 


\section{Introduction}

In most cities, the increase of air quality deterioration has reached a level that affects the population's health. One of the most serious pollutants are atmospheric particles, such as dust, pollen, carbon and metals like lead and cadmium, asbestos, salts, sulfuric acid droplets, dioxins, pesticides, etc. [1], that remain suspended in the atmosphere.

These particles are capable of blocking the respiratory system air defense mechanisms at the upper airway level and alveoli which may carry biological elements such as pollen, bacteria, fungi and viruses that are conducted to the lungs. Particles larger than 10 microns are retained primarily in the upper respiratory tract; particles which are less than 10 microns remain in the breathable fraction and penetrate into the alveolar space of the lungs, Mexican Official Norm (NOM) [2]. High concentration of airborne particles can cause or worsen cardiovascular and lung diseases, heart attacks and arrhythmias, they also affect the central nervous and reproductive systems and may cause cancer [3] [4].

The atmosphere lacks a native microbiota, which acts as a dispersion medium for many types of microorganisms (spores, bacteria, viruses and fungi), from others environments. Microorganisms dispersed into the air have a high biological and economic importance; they also produce illness in plants, animals and human beings since they can quickly be transported in bioaerosol forms causing alterations in foods and organic materials, and contribute to the deterioration and corrosion of monuments and metal buildings.

Several viral, bacterial and fungal infections of human beings and animals are airborne transmitted and often produce epidemic outbreaks. These can be classified into respiratory diseases (pneumonia, whooping cough, tuberculosis, legionellosis, cold, flu), systemic diseases (meningitis, measles, varicella, fungal infections) and allergies [5]. Acute respiratory infections are not produced by inert particles, but by a microorganism that is associated to them, therefore the importance of biological identification of $\mathrm{PM}_{10}$ and TSP.

In the city of Hermosillo, Mexico, the number of cases of Acute Respiratory Infections (ARI's) between 2006 and 2010, were provided by the Sonora State Children's Hospital. The number of ARI's between 2006 and 2010 affected mainly children ranging ages from 1 to 4 years. The causal agents of these infections were, among others, Klebsiella pneumoniae sub pneumoniae and Pseudomonas.

Microbiological analysis of atmospheric particles including infectious, allergens and fungal agents among others, were determined by capturing them in solid, liquid or agar media for subsequent qualitative or quantitative analysis using biochemical, microscopic, immunochemical, microbiological and molecular techniques, that offer various degrees of sensitivity and specificity [6]. Many of the aerosols sampling devices use particle separation methods from airflow through capture in preselected medium. More common sampling methods used to separate and capture bioaerosols include impaction, filtration and impingement. Impaction method employs a surface of a broad spectrum solid medium (agar); the filtration uses a membrane filter and the impingement an isotonic liquid medium (water-based) [7]. These techniques are used for low volume samples and work for small periods (minutes).

The main goal of this investigation was to identify the microflora present in the air of Hermosillo, México, using high volume samplers, which suck air from the environment and retain particles in glass and quartz microfiber filters. Then the particles were analyzed using biochemical techniques for microorganism identification. As we know, there are no previous studies on bacterial analysis of air quality using this type of filters with samples of $\mathrm{PM}_{10}$ or TSP.

\section{Methodology}

Three sampling periods were analyzed during 2011; February 8 to 26, April 27 to May 15 and August 25 to September 12 at four different sampling stations. Samples were obtained every six days at each sampling station following the NOM protocol. For the $\mathrm{PM}_{10}$ a Wedding and Associated Brand high volume sampler was employed using quartz filters (Whatman), whereas for TSP sampling, a high volume sampler TSP model TE-5000 with fiber glass filter was used. The size of the filter was 20.3 x $25.4 \mathrm{~cm}$. For $\mathrm{PM}_{10}$, the sample had a continuous flow of 1.02 to $1.24 \mathrm{~m}^{3} / \mathrm{min}$, and 1.1 to $1.7 \mathrm{~m}^{3} / \mathrm{min}$ for TSP, for 24 consecutive hours. The samplers used are property of Municipal Institute of Ecology and employees through the program assessment of air quality.

\subsection{Sample Locations}

High volume samples were strategically located in four sampling stations in the city, being each one of these: 
South station: COBACH High School; coordinates $29^{\circ} 02^{\prime} 40.15^{\prime \prime} \mathrm{N}$ and $110^{\circ} 57^{\prime} 30.46^{\prime \prime} \mathrm{W}$. This site is surrounded by residential and commercial offices, high traffic areas and unpaved roads.

Central station: Direction of Inspection and Vigilance Building of the City of Hermosillo; coordinates $29^{\circ} 04^{\prime} 44.01 " \mathrm{~N}$ and $110^{\circ} 56^{\prime} 31.91^{\prime \prime} \mathrm{W}$. Surrounded by residential and commercial offices and high traffic areas.

North station: Sonora State University (UES); $29^{\circ} 07^{\prime} 17.70^{\prime \prime N}$ and $110^{\circ} 57^{\prime} 40.12^{\prime \prime}$ W. Surrounded by residential and medium traffic areas.

Northwest station: CBTIS 206 High School; located at $29^{\circ} 07^{\prime} 07.25^{\prime \prime N}$ and $111^{\circ} 00^{\prime 23.86 " W . ~ S u r r o u n d e d ~ b y ~}$ residential areas and unpaved roads. Figure 1 shows the four sampling sites.

\subsection{Stabilization of Filters}

The filters were stabilized and weighed before and after sampling under the same conditions of temperature and humidity. Filters were kept for 24 hours in a desiccator with humidity indicator. An analytical electronic balance was used, Sartorius Brand model A200S-D1B installed on anti-vibration table. The filters were handled using powder-free gloves.

\subsection{Calculation of Particles Concentration $\mathrm{PM}_{10}$ and TSP in the Air}

The concentration of particulate matter in air at standard conditions $(\mathrm{P}=760 \mathrm{mmHg}$ and $\mathrm{T}=298 \mathrm{~K})$ is determined by the mass of collected particles and the volume of air suctioned by the equipment during the sampling time (24 hours) following the protocol established in the Code Federal Regulation from United State Environmental Protection Agency [8].

\subsubsection{Concentration of $\mathrm{PM}_{10}$}

The equation used for calculating $\mathrm{PM}_{10}$ concentration (1):

$$
P M_{10}=\frac{(P 2-P 1) \times 10^{6}}{V}
$$

where P1= Initial weight; P2 = Final weight; V = Volume of air sampled.

Air sampled volume is calculated by Equation (2):

$$
V=Q_{\text {std }} \times 60 \times \text { sampling hours }
$$

where: Qstd = Standard flow

Air sampled volume

Standard flow was determined by Equation (3):

$$
Q_{\text {std }}=\frac{Q_{a}(\text { Average pressure during sampling } \times 298 K)}{760 \mathrm{mmHg} \times \text { Average temperature during sampling }}
$$

where: Qa = Current volumetric flow

We obtained the current volumetric flow by using the Look Up Table (manual) where we calculated ratio pressure $(\mathrm{Po} / \mathrm{Pa})$ using formula (4):

$$
\frac{P_{o}}{P_{a}}=1-\left(\frac{P_{f}}{P_{a}}\right)
$$

where

$\mathrm{Pa}=$ Standard pressure $(760 \mathrm{mmHg})$.

$\mathrm{Pf}=$ Average pressure drop.

where: Pf was determined by Equation (5):

$$
P_{f}=\frac{\text { Inches of } \mathrm{H}_{2} \mathrm{O}}{13.6 \times 25.4}
$$

The average equipment pressure drop was determined using data readings taken before and at the end of sampling with water manometer. 


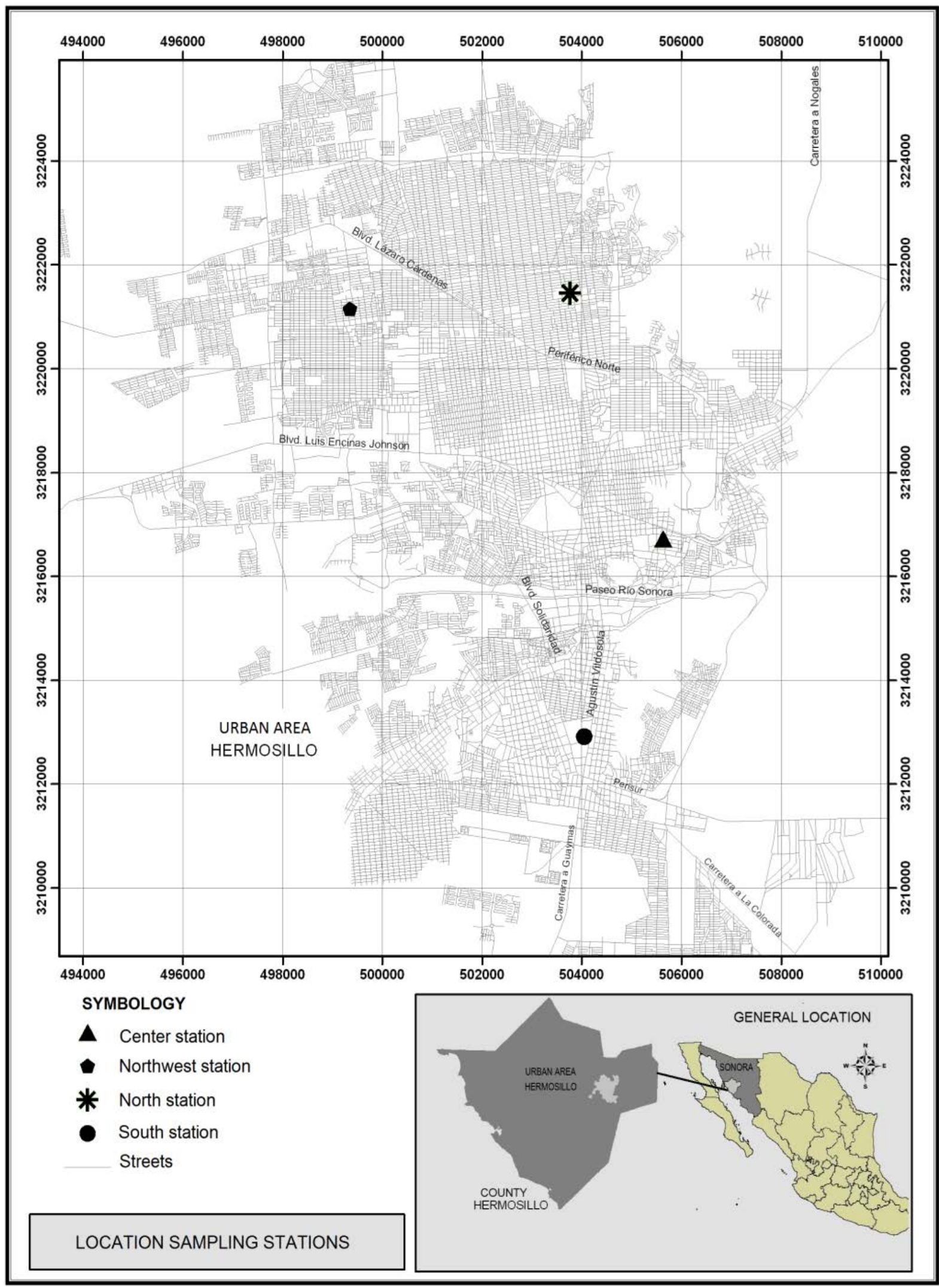

Figure 1. Sampling locations. 


\subsubsection{Concentration of TSP}

The equation used for calculating the concentration of TSP (6):

$$
T S P=\frac{(P 2-P 1) \times 10^{6}}{V}
$$

where P1= Initial weight; P2 = Final weight; $\mathrm{V}$ = Volume.

The volume is calculated with equation (7):

$$
V=Q_{p t n} x t
$$

where: $\mathrm{Q}_{\mathrm{ptn}}=$ Standard flow; $\mathrm{t}=$ Time.

For calculating $\mathrm{Q}_{\mathrm{ptn}}$ Equation (8) was used:

$$
Q_{p t n}=\frac{1}{m}\left[\left(I \sqrt{\frac{P_{3}}{P_{p t n}} \frac{T_{p t n}}{T_{3}}}\right)-b\right]
$$

where:

$\mathrm{M}$ = Slope of the sampler calibration curve.

$\mathrm{I}=$ Average flow indicated in the flow recorder (letter Dickson).

P3 = Average flow indicated in the flow recorder (letter Dickson).

$\mathrm{T} 3=$ Average temperature during the sampling period (in Kelvin degrees).

Pptn $=$ Standard pressure $(101 \mathrm{kPa}$ or $760 \mathrm{mmHg})$.

Tptn = Standard temperature (in Kelvin degrees, 298).

$\mathrm{B}=$ Intersection point of the sampler calibration curve line.

\subsection{Sampling for Bacteriological Analysis}

Samples for analysis were obtained from the filters $\mathrm{PM}_{10}$ and TSP in which small portions were taken with an area of $28.27 \mathrm{~mm}^{2}$. The number of samples per filter was calculated taking into consideration that the filter has a sampling area of $41,617.50 \mathrm{~mm}^{2}$ and a volume of $1627.20 \mathrm{~m}^{3}$ of air sampled in 24 hours. The unit sample area considered was $28.27 \mathrm{~mm}^{2}$ because it is the standard measure. Canon and Roe's formula was used, considering that expected prevalence of bacteria on the filter was $50 \%$ and sensitivity of the techniques employed $95 \%$. According to these operations, the number of sampling units was four.

\subsection{Bacteriological Analysis}

Samples taken from the filters were placed in tubes containing nutritive broth BHI (Brain Heart Infusion) and incubated at $37^{\circ} \mathrm{C}$ for 24 hours. The following enriched culture mediums were used for sample incubation: Blood and chocolate agar. Colonies were selected according to morphological differentiation and Gram staining was used to differentiate cell morphology. To gram positive cocci, a catalase test was applied to differentiate Micrococaceae and Streptococaceae family. The gram positive cocci catalase negative was cultured in selective medium KF. Gram negative bacilli were cultured in MacConkey agar and the harvested microorganisms were tested with oxidase. The identification of the isolated microorganisms was done by a biochemical test recommended in Bergey's Manual [9] for each particular case.

Colony forming units (CFU) were counted from the total microorganisms in the filters. The concentration was calculated for a sample area of $41,617.50 \mathrm{~mm}^{2}$ and a volume of air sampled of $1627.20 \mathrm{~m}^{3}$ in 24 hours and in accordance with the procedures established on NOM [10].

\subsection{Statistical Analysis}

A SigmaPlot 11 software was used to determine statistical analysis using one way ANOVA.

\section{Results}

\subsection{Respiratory Infections in Hermosillo's Population}

Acute respiratory infections are not produced by inert particles, but by a microorganism that is associated to 
them. In the city of Hermosillo, ARI's affects mainly people in ages between 1 and 4 years (as shown in Figure 2). The most common infections are: Klebsiella pneumoniae sub pneumoniae and Pseudomonas. However, there is no evidence that these bacteria are airborne.

\subsection{Concentration of $\mathrm{PM}_{10}$ and TSP}

Comparing the $\mathrm{PM}_{10}$ concentrations values found in each of the sampling dates with the value of the maximum permitted concentration established by the Mexican Official Norm [11] which is $120 \mu \mathrm{g} / \mathrm{m}^{3}$, only the South Station exceeded the permitted concentration during the second sampling period, with a value of $139.71 \mu \mathrm{g} / \mathrm{m}^{3}$. TSP concentration values obtained in all sampling dates were below the Mexican Official Norms. In Figure 3, particles concentration and maximum permissible by NOM is observed.

\subsection{Identified Microorganisms}

The results of the microbiological analysis, using traditional techniques, revealed the presence of microorganisms associated with respiratory diseases, such as Klebsiella pneumoniae sub pneumoniae and Citrobacter sp10 mainly. Besides Enterococcus faecalis, other bacteria present in samples were the Pseudomonas genus and the Enterobacteriaceae family.

In the south and northwest sampling locations, E. faecalis was found in $50 \%$ of the samples, $100 \%$ in the center location and $33 \%$ in the north one. In the center and north locations, Klebsiellapneumoniae sub pneumoniae was found on February 8. Citrobacter sp.10 was found once in the south and northwest locations, each in different dates. Butiauxella agrestis and Proteus penneri were found only in the south location. On May 15, Salmonella paratyphi $A$ and Enterobacter sacazakii were found in the northwest location. Table 1 shows the microorganisms found and Figure 4 shows the results of CFU at each station and period analyzed.

\subsection{Antibiotic Sensitivity Analysis}

Since $E$. faecalis was the microorganism with higher number of appearances, an antibiotic sensitivity analysis was performed with the support of a local laboratory. (LaboratoriosAcuña, Hermosillo, Mexico). Results can be observed in Table 2.

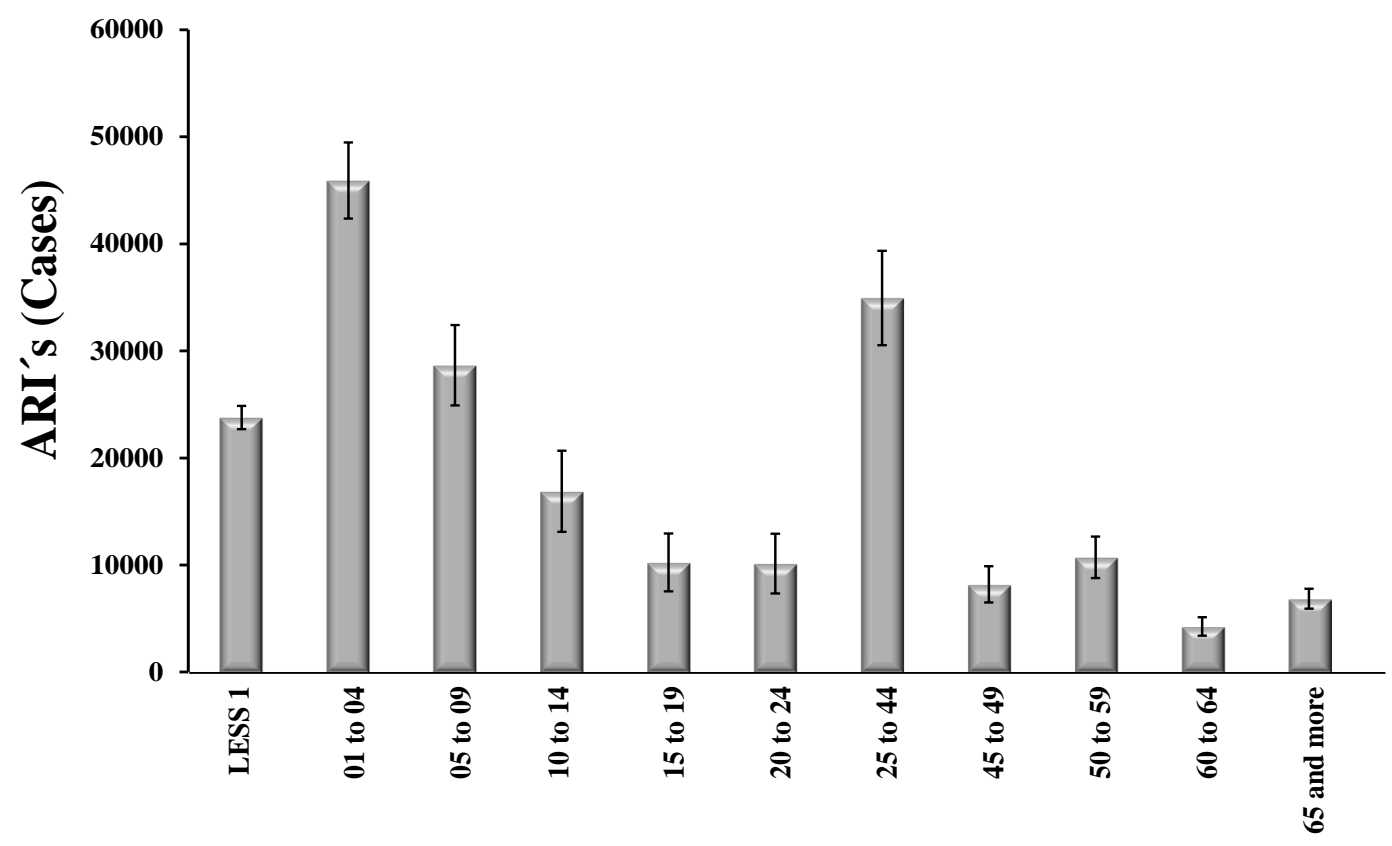

Figure 2. Number of ARI's in the city of Hermosillo, México, during the period 2006-2010, Source: Children's Hospital of the State of Sonora (HIES). 


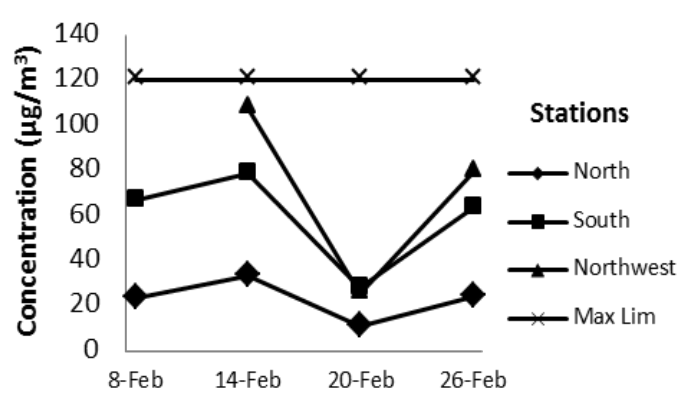

a)

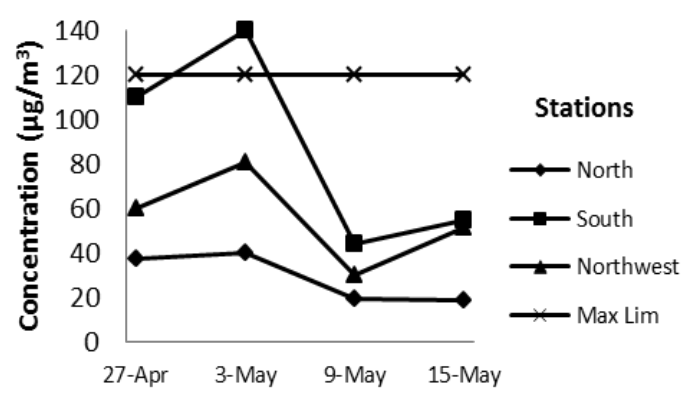

b)

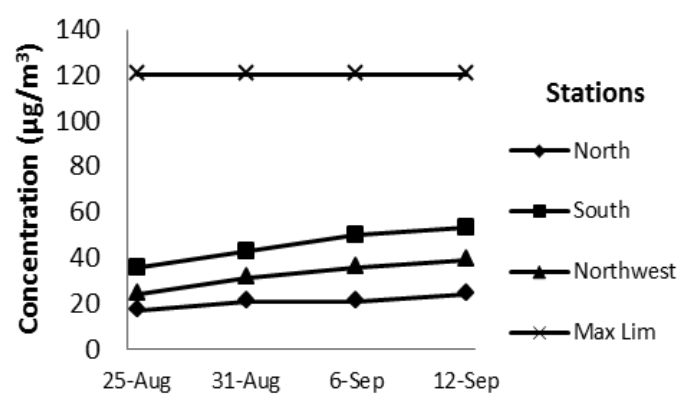

c)

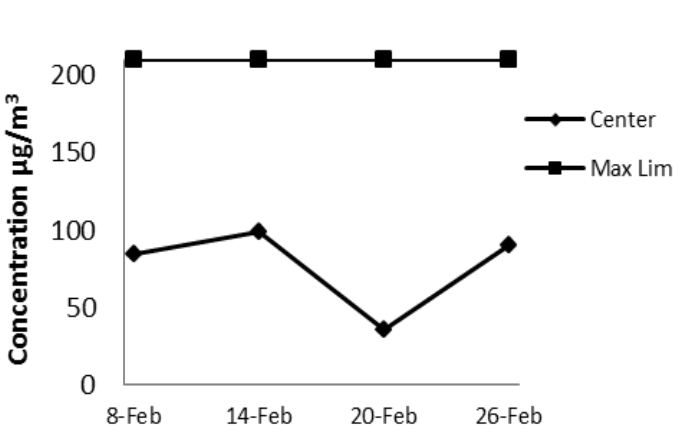

d)

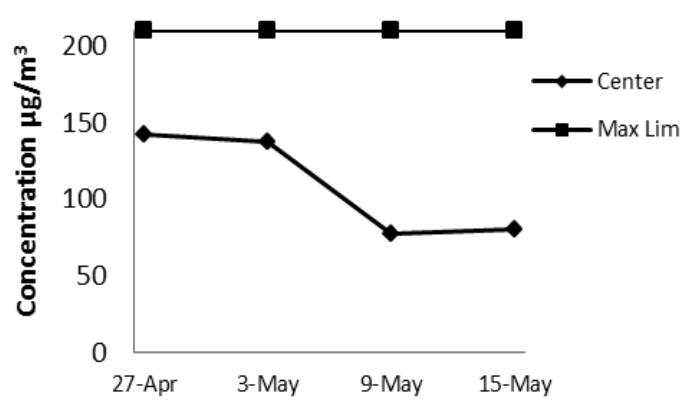

e)

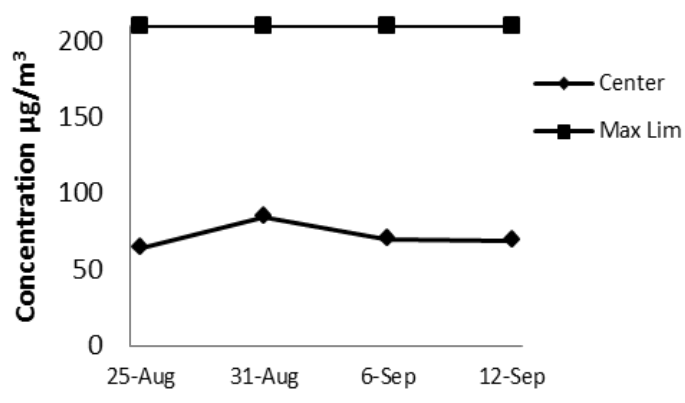

f)

Figure 3. $\mathrm{PM}_{10}$ concentration in different sampling sites a) First sample, b) Second sample, c) Third sample and TSP d) First sample, e) Second sample, $\mathrm{f})$ Third sample.There is not a statistically significant between sampling dates North $(\mathrm{P}=0.421)$, South $(\mathrm{P}=0.201)$, Northwest $(\mathrm{P}=0.344)$ and Center $(\mathrm{P}=0.154)$.

\section{Discussion}

Air pollution has been widely studied in different countries to identify potential risks of respiratory diseases in human beings. However, the main focus of these studies is about air chemical contamination regarding the presence of carbon monoxide $(\mathrm{CO})$, sulfur dioxide $\left(\mathrm{SO}_{2}\right)$, nitrogen oxides $\left(\mathrm{NO}_{\mathrm{x}}\right.$ and $\left.\mathrm{NO}_{\mathrm{y}}\right)$, reduced nitrogen (ammonia, $\mathrm{NH}_{3}$; ammonium, $\mathrm{NH}_{4}$ ), ozone $\left(\mathrm{O}_{3}\right)$ [12]-[17], heavy metals [18] [19] and particulate matter $\mathrm{PM}_{10}$ [12] [20] [21].

Some authors have been analyzing the possible transmission of pathogens through air, but these studies have been targeted to areas where high content of potential pathogens are present, such as water treatment plants and garbage dumps [22]. Few investigations have been done to look for biological contaminants in the air; the most common is the search for particles that cause allergic diseases such as pollen [23] [24]. 


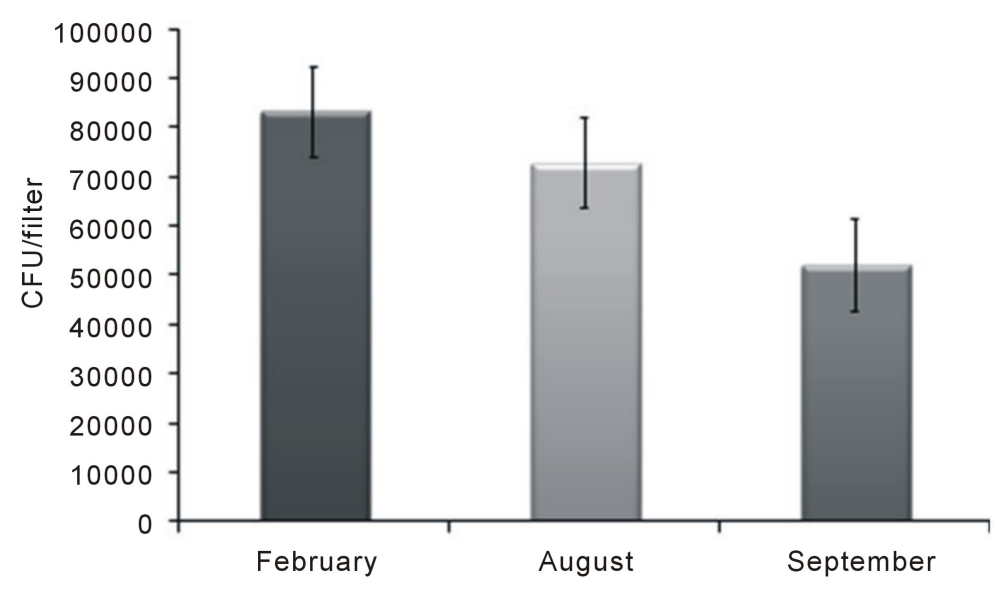

(a)

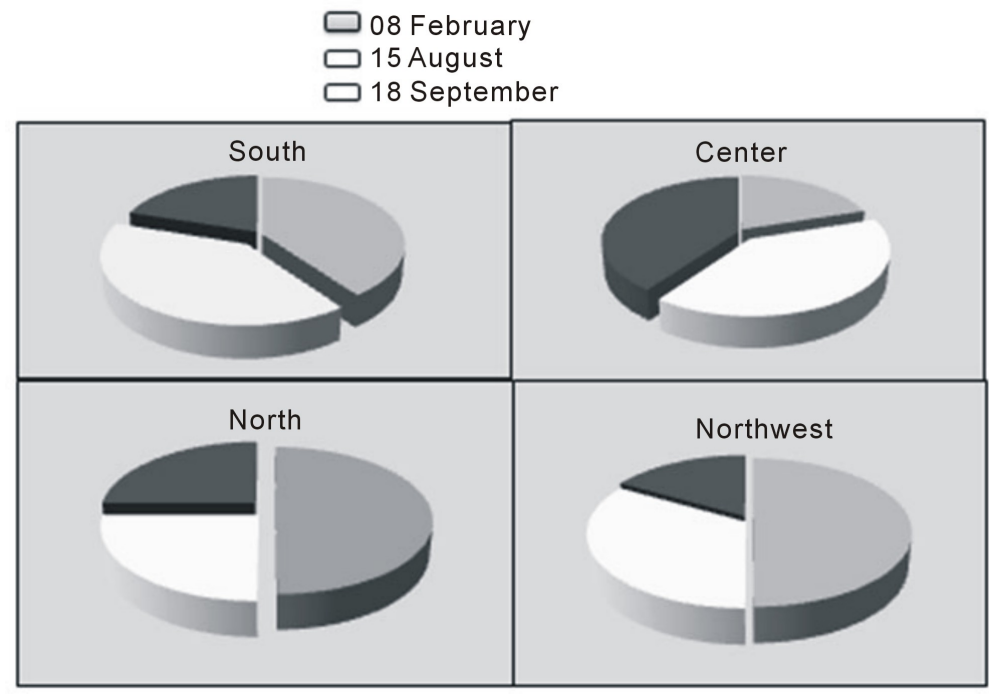

(b)

Figure 4. CFU of mesophylls bacteria obtained at each sampling location at three different periods (a). Sampled area distribution (b). There is not a statistically significant between sampling dates $(\mathrm{P}=0.274)$.

Table 1. Microorganisms identified using traditional biochemical tests.

\begin{tabular}{|c|c|c|c|c|c|c|}
\hline Zones & 08-feb & 26-feb & 27-abr & 15-may & 25-ago & 18-sep \\
\hline \multirow[t]{2}{*}{ South } & Butiauxellaagrestis & $\begin{array}{c}\text { E. faecalis } \\
\text { Proteus penneri }\end{array}$ & E. faecalis & Enterobacterias & & E. faecalis \\
\hline & & Citrobacter sp. 10 & & & & \\
\hline Center & $\begin{array}{c}\text { E. faecalis } \\
\text { Klebsiella pneumoniae sub } \\
\text { pneumoniae }\end{array}$ & $\begin{array}{c}\text { E. faecalis } \\
\text { Pseudomonas }\end{array}$ & $\begin{array}{c}\text { E. faecalis } \\
\text { Cedecea sp. } 3\end{array}$ & $\begin{array}{c}\text { E. faecalis } \\
\text { Enterobacterias }\end{array}$ & E. faecalis & E. faecalis \\
\hline North & $\begin{array}{c}\text { E. faecalis } \\
\text { Klebsiella pneumoniae sub } \\
\text { pneumoniae }\end{array}$ & Pseudomonas & & E. faecalis & & \\
\hline Northwest & Pseudomonas sp. & & E. faecalis & $\begin{array}{c}\text { E. faecalis Citrobacter sp.10 } \\
\text { Salmonella paratyphi A } \\
\text { Enterobacter sakazakii }\end{array}$ & E. faecalis & \\
\hline
\end{tabular}


Table 2. Antibiotic sensitivity test of 6 isolated of $E$. faecalis.

\begin{tabular}{|c|c|c|c|c|c|c|}
\hline ANTIBIOTIC & 1 & 2 & 3 & 4 & 5 & 6 \\
\hline Ampicillin & $\mathbf{R}$ & $\mathrm{S}$ & $\mathbf{R}$ & MR & S & $\mathrm{S}$ \\
\hline Azithromycin & MR & MR & MR & $\mathbf{R}$ & S & MR \\
\hline Ciprofloxacin & MR & MR & MR & $\mathbf{R}$ & S & MR \\
\hline Clarithromycin & S & S & $\mathbf{R}$ & S & MR & $\mathrm{S}$ \\
\hline Erythromycin & $\mathbf{R}$ & S & $\mathbf{R}$ & $\mathbf{R}$ & $\mathbf{R}$ & MR \\
\hline Nitrofurantoin & $\mathbf{R}$ & S & S & S & MR & $\mathrm{S}$ \\
\hline Fosfomycin & $\mathbf{R}$ & $\mathbf{R}$ & $\mathbf{R}$ & $\mathbf{R}$ & S & MR \\
\hline Gentamicin & $\mathbf{R}$ & $\mathbf{R}$ & $\mathbf{R}$ & S & $\mathbf{R}$ & $\mathrm{S}$ \\
\hline Llevofloxacin & S & S & MR & MR & S & MR \\
\hline Norfloxacin & MR & S & S & MR & S & $\mathrm{S}$ \\
\hline Ofloxacin & MR & MR & S & $\mathbf{R}$ & MR & MR \\
\hline Penicillin G & $\mathbf{R}$ & S & S & $\mathbf{R}$ & $\mathrm{S}$ & $\mathbf{R}$ \\
\hline Rifampicin & MR & MR & $\mathbf{R}$ & MR & MR & MR \\
\hline Cotrimoxazole & S & MR & MR & MR & MR & MR \\
\hline Tetracycline & MR & S & S & S & S & $\mathrm{S}$ \\
\hline Vancomycin & S & S & S & S & S & $\mathrm{S}$ \\
\hline
\end{tabular}

$\mathbf{S}=$ Sensitive; $\mathbf{M R}=$ Moterately Resistant; $\mathbf{R}=$ Resistant.

The concentration of $\mathrm{PM}_{10}$ was analyzed in four different locations in the city of Hermosillo, México. Concentration levels above the Mexican Standard Norms where only observed during May, in the south location. The results indicate that Hermosillo, at least in 2011, did not present mayor problems of pollution for $\mathrm{PM}_{10}$ in the sampled areas.

This investigation also covered the analysis of filters containing particles $\mathrm{PM}_{10}$ and TSP to determine the load and variety of bacteria. The results demonstrated a high bacterial concentration in the city's air. The greatest concentration was observed in February and the lowest in September.

When bacterial concentration was analyzed separately, the lowest number of bacteria was observed during February for the south location and in August for the north location. The highest degree of bacterial air pollution was found in the central area of the city.

Cases of acute respiratory infections (ARI's) in the city occur mainly in younger age groups, as shown in Figure 2. The pathogens identified as generators of these ARI's were, Klebsiella pneumoniae sub pneumoniae and Pseudomonas, among others. It was possible to isolate the bacteria found in the air samples; therefore the conclusion is that air is one of the main routes of transmission of pathogens of ARI's.

In the analysis of isolated bacteria, genres that cause health problems were identified. The most vulnerable population groups are children and the elderly. Some of these bacteria such as Klebsiella pneumoniae sub pneumoniae and Pseudomonas sp. are opportunistic pathogens of nosocomial infections (intra hospital), while Salmonella paratyphi A, E. faecalis and generally Enterobacteriaceae cause intestinal infections when contaminated foods are consumed. Contamination means of these foods can be direct (hands and contaminated water) or, as demonstrated in this work, air.

Isolated colonies of $E$. faecalis were resistant to almost all antibiotics and in most cases; patients receiving treatment for this bacteria will generally not be effective. According to the presented results, vancomycin is the only antibiotic recommended to treat affected patients by this type of bacteria. Due to the toxicity level of this antibiotic, it is recommended to use it as a last option treatment.

This is the first report of systematic measurements looking for bacterial air contamination. The results shown in this paper suggests that respiratory tract pathogenic bacteria can be transported through the air. Specific pathogens research such as Mycobacterium tuberculosis, Streptococcus pneumoniae, Haemophyllus influenzae and coccidioides sp. is still necessary.

\section{References}

[1] Sepúlveda, J.D. (2004) MorphologicalProfile and Elemental Chemical of Respirable Particulateson Punctual Emission 
Sources and Environmental Sampling (Perfil Morfológico y Químico Elemental de Partículas Respirables en Fuentes de Emisión Puntual y Muestreos Ambientales). Informe Final INE-CENICA, México.

[2] SSA (2005) Official Mexican Standard NOM-025-SSA1-1993, Environmental Health. Criteria for Assessing the Allowable Limit for the Concentration of Particulate Matter, Permissible Limit for the Concentration of Total Suspended Particles TSP, Particles Less than 10 Microns PM10 and Particles Smaller than 2.5 Micrometers PM2.5 of Ambient Air Quality. Criteriaforassessingthe Air Quality (SSA 2005) Norma Oficial Mexicana NOM-025-SSA1-1993, Salud Ambiental. Criterios para Evaluar el valor Límite Permisible para la Concentración de Material Particulado. Valor Límite Permisible para la Concentración de Partículas Suspendidas Totales PST, Partículas Menores de 10 Micrómetros PM10 y Partículas Menores de 2.5 Micrómetros PM2.5 de la Calidad del Aire Ambiente Criterios para Evaluar la calidad del Aire). Diario Oficial de la Federación, México.

[3] Cruz, M.E., Gómez, A., Quintero, M. and Varela, J. (2013) Assessment of Air QualityRegarding Total Suspended Particles (TSP) and Heavy Metals (Pb, Cd, Ni, Cu, Cr) in Thecity of Hermosillo, Sonora, Mexico, duringan Annual Period (Evaluación de la Calidad del Aire Respecto de Partículas Suspendidas Totales (PST) y Metales Pesados (Pb, $\mathrm{Cd}, \mathrm{Ni}, \mathrm{Cu}, \mathrm{Cr}$ ) en la Ciudad de Hermosillo, Sonora, México, Durante un Periodo Anual). Revista Internacional de Contaminación Ambiental, 29, 269-283. http://200.77.231.100/work/normas/noms/2005/025ssa12005.pdf

[4] Kappos, A.D., et al. (2004) Health Effects of Particles in Ambient Air. International Journal of Hygiene and Environmental Health, 207, 399-407.

[5] de la Rosa, M.C., Mosso, M.A. and Ullán, C. (2002) The Air: Habitat and Transmission of Microorganismsvia (El Aire: Hábitat y Medio de Transmisión de Microorganismos). Observatorio Medioambiental, 5, 375-402.

[6] Reoun, H., Mainelisa, G. and White, L. (2006) Development and Calibration of Real-time PCR for Quantification of Airborne Microorganisms in Air Samples. Atmospheric Environment, 40, 7924-7939. http://dx.doi.org/10.1016/j.atmosenv.2006.07.020

[7] Jensen, P.A., Cih, P.E. and Schafer, M.P. (1998) Sampling and Characterization of Bioaerosols. NIOSH Manual of Analytical Methods NIOSH/DPSE, Chapter 2.

[8] USEPA (1992) 40 CFR Ch. I Pt. 50, App. B-Reference Method for the Determination of Suspended Particulate Matter in the Atmosphere (High-Volume Method). United States Environmental Protection Agency-Code of Federal Regulations, Washington DC.

[9] Breed, R.S., Murray, E.G.D. and Smith, N.R. (1957) Bergey’s Manual Determinative Bacteriology. 7th Edition, The Williams \& Wilkins Company, Baltimore.

[10] SSA (Ministry of Health United States of Mexico) (1994) Mexican Official Standard NOM-113-SSA1-1994. Goods and Services. Counting Method for Total Coliform Microorganisms in plate (SSA, Secretaría de Salud Estados Unidos Mexicanos (Norma Oficial Mexicana NOM-113-SSA1-1994. Bienes y Servicios. Método para la Cuenta de Microorganismos Coliformes Totales en Placa). Diario Oficial de la Federación, México.

[11] SSA (Ministry of Health United States of Mexico) (1994) Mexican Official Standard NOM-024-SSA1-1993. Environmental Health. Criteria for Assessing Ambient Air Quality with Respect to Total Suspended Particles (TSP). Allowable Value for the Concentration of Total Suspended Particles (TSP) in Ambient Air as a Protection to the Population's Health (SSA, Secretaría de Salud Estados Unidos Mexicanos, Norma Oficial Mexicana NOM-024-SSA1-1993. Salud Ambiental. Criterio para evaluar la calidad del aire ambiente con respecto a partículas suspendidas totales (PST). Valor permisible para la concentración de partículas suspendidas totales (PST) en el aire ambiente como medida de protección a la salud de la población). Diario Oficial de la Federación, México.

[12] Aceves, M.A., et al. (2012) Analysis of Key Features of Non-Linear Behavior Using Recurrence Plots, Case Study: Urban Pollution in Mexico City. Journal of Environmental Protection, 3, 1147-1160. http://dx.doi.org/10.4236/jep.2012.329133

[13] Capilla, C. (2012) Application of Statistical Methods to Assess Carbon Monoxide Pollution Variations within an Urban Area. International Journal of Geosciences, 3, 885-890. http://dx.doi.org/10.4236/ijg.2012.325090

[14] Naddafi, K., Sowlat, M.H. and Safari, M.H. (2012) Integrated Assessment of Air Pollution in Tehran, Over the Period from September 2008 to September 2009. Iranian Journal of Public Health, 41, 77-86.

[15] Kabashi, S., et al. (2012) Dynamic Modeling of Air Pollution and Acid Rain from Energy System and Transport in Kosovo. Open Journal of Air Pollution, 1, 82-96. http://dx.doi.org/10.4236/ojap.2012.13011

[16] Blanchard, C.L., Hidy, G.M., Tanenbaum, S., Edgerton, E.S. and Hartsell, B.E. (2013) The Southeastern Aerosol Research and Characterization (SEARCH) Study: Spatial Variations and Chemical Climatology, 1999-2010. Journal of the Air \& Waste Management Association, 63, 260-275. http://dx.doi.org/10.1080/10962247.2012.749816

[17] Restrepo, C.E., Simonoff, J.S., Thurston, G.D. and Zimmerman, R. (2012) Asthma Hospital Admissions and Ambient Air Pollutant Concentrations in New York City. Journal of Environmental Protection, 3, 1102-1116. http://dx.doi.org/10.4236/jep.2012.329129 
[18] Spangler, J.G. (2012) Diabetes Mortality and Environmental Heavy Metals in North Carolina Counties: An Ecological Study. Journal of Diabetes Mellitus, 2, 369-372. http://dx.doi.org/10.4236/jdm.2012.24057

[19] Monick, M.M., et al. (2013) Effects of Eyjafjallajökull Volcanic Ash on Innate Immune System Responses and Bacterial Growth in Vitro. Environmental Health Perspectives, 121, 691-698. http://dx.doi.org/10.1289/ehp.1206004

[20] Newth, D. and Gunasekera, D. (2012) An Integrated Agent-Based Framework for Assessing Air Pollution Impacts. Journal of Environmental Protection, 3, 1135-1146. http://dx.doi.org/10.4236/jep.2012.329132

[21] Vivanco, M.G., et al. (2012) Impact of the Transboundary Transport of Air Pollutants on Air Quality in Spain. Journal of Environmental Protection, 3, 1167-1175. http://dx.doi.org/10.4236/jep.2012.329135

[22] Kalwasińska, A., Burkowska, A. and Swiontek, M. (In Press) Exposure of Workers of Municipal Landfill Site to Bacterial and Fungal Aerosol. Clean—Soil, Air and Water. http://onlinelibrary.wiley.com/doi/10.1002/clen.201300385/pdf

[23] Ghosh, D., et al. (2012) Associations between Pollen Counts, Pollutants and Asthma-Related Hospital Admissions in a High-Density Indian Metropolis. Journal of Asthma, 49, 792-799. http://dx.doi.org/10.3109/02770903.2012.716473

[24] Duro, A., Piccione, V. and Zampino, D. (2013) Air Quality Biomonitoring through Pollen Viability of Fabaceae. Environmental Monitoring and Assessment, 185, 3803-3817. http://dx.doi.org/10.1007/s10661-012-2829-0 